\title{
QUEEN'S
UNIVERSITY
BELFAST
}

\section{Scratched, Stained, and Damaged: The Intersection of Projection Booth Problems and Hollywood Film Aesthetics}

Rhodes, G. D. (2017). Scratched, Stained, and Damaged: The Intersection of Projection Booth Problems and Hollywood Film Aesthetics. Quarterly Review of Film and Video, 34(8), 707-724.

https://doi.org/10.1080/10509208.2017.1344053

\section{Published in:}

Quarterly Review of Film and Video

\section{Document Version:}

Peer reviewed version

Queen's University Belfast - Research Portal:

Link to publication record in Queen's University Belfast Research Portal

\section{Publisher rights}

Copyright 2017 Taylor and Francis. This work is made available online in accordance with the publisher's policies. Please refer to any applicable terms of use of the publisher.

\section{General rights}

Copyright for the publications made accessible via the Queen's University Belfast Research Portal is retained by the author(s) and / or other copyright owners and it is a condition of accessing these publications that users recognise and abide by the legal requirements associated with these rights.

Take down policy

The Research Portal is Queen's institutional repository that provides access to Queen's research output. Every effort has been made to ensure that content in the Research Portal does not infringe any person's rights, or applicable UK laws. If you discover content in the Research Portal that you believe breaches copyright or violates any law, please contact openaccess@qub.ac.uk. 
Scratched, Stained, and Damaged:

The Intersection of Projection Booth Problems

and

Hollywood Film Aesthetics

By Gary D. Rhodes

No matter how topical the subject, how beautiful the color, how unique the photography, a roll of film is practically worthless with a big scratch running down the middle.

- Francis W. Decker, The American Archivist (357)

The physical texture of film is unstable. It decomposes. As the title of Anthony Slide's 1992 monograph warns, Nitrate Won't Wait. Nitro-cellulose footage deteriorates, as heralded in such found-footage films as Peter Delpeut's Lyrical Nitrate (1991) and Bill Nichols’ Decasia: The State of Decay (2002). Safety stock degrades as well. One can immediately think of certain 1970s-era $35 \mathrm{~mm}$ films with their fading color, and the restorations required of such movies as Jaws (Steven Spielberg, 1976). As Paolo Cherchi Usuai has observed, the process of decay "can be contained or decelerated, but not altogether avoided" (17).

The technical quality of film faces other obstacles as well. Filmmaker, historian, and restorationist Kevin Brownlow emphasizes this point when - in the documentary Unknown Chaplin (1983) - he juxtaposes two examples of the same Charlie Chaplin footage, one image presenting a close approximation of its original 
appearance and the second being a poor quality copy of several generations. Duplicating a film does not create a full-quality duplicate. Sometimes it even yields other problems, as in the horizontal line that plagues the top five percent of the frame in the earliest surviving copy of Das Cabinet des Dr. Caligari (Robert Wiene, 1920). Most subsequent dupes over the years cropped out the line, preferring to alter Caligari's visual composition than to allow for an imperfection to remain visible.

Observable flaws in the life of a film print can also occur through its sheer projection. Watching a film can damage it, even though its projection arguably represents the period of time in which it is most completely a film. A print might physically exist in a can, but it cannot be experienced unless it is screened, and that process is fraught with potential perils. The damage might be temporary, as in the case of hairs or fuzz in the projector gate (or on dirty film, such as footage that has made contact with the floor of the projection booth) that are thus illuminated. A particular screening (or number of screenings) might be marred until the print and projector are cleaned. For decades, the very film exchanges that acted as a conduit between Hollywood studios and U.S. theatres saw the act of cleaning prints as one of their key responsibilities. ${ }^{1}$ More permanent damage can result from liquids coming into contact with the film. A beverage in the projection booth can spill onto given frames and create stains. Oil in the projector can also cause stains, as well as the greater potential for unwanted material like dust to adhere to given frames.

However, the most common flaws are scratches. In 1933, the International Projectionist noted that, "scratch marks on film [are] probably the outstanding difficulty with which projectionists have to contend" ("Projector Head" 22). And they had to contend with it from the earliest days of the cinema. In 1902, for example, Siegmund Lubin attempted to assure buyers of his films that they could not 
scratch, an overstatement to be sure (Advertisement 856). All motion picture film is capable of becoming scratched, whether the negatives from which positives are made or the release prints audiences view.

Film projection can also create minor specks and spots on prints. However, scratches are generally more noticeable, whether running across a small number of frames and appearing onscreen rapidly (as if they are a flash of lightning), or even appearing consistently over several seconds or minutes of footage. Most viewers notice scratches readily, as they are usually darker than the surrounding visual information and they obscure that which has been deleted: the scratch thus becomes a prominent and generally unwanted part of the image.

Flaws like scratches could occur outside of the projection booth, whether at the laboratories striking prints or at film exchanges handling them. Nevertheless, the bulk of these flaws occurred inside projection booths, due either to poor quality and/or dirty equipment or to equipment not properly operated. Projector heads could scratch films if the rollers in the upper or lower magazines were worn and/or dirty, as could worn film trap shoes and worn or damaged aperture plates. Likewise, scratches could result from oversized loops in the projector head, too much tension on the takeup reel, rewinders out of alignment, rewinders with bent reels, and/or the rewinding of film reels at excessive speeds (Richardson 97).

In short, the specific causes of scratches in the projection booth were (and remain) numerous, but the bulk of them could be collectively understood as caused by what the International Projectionist once called a "hard or gritty substance which contacts the film, and has moved over the surface [of it], usually lengthwise" (Schroeder 7). Repeated projection of a print with scratches can also make the original scratches more apparent to the viewer's eye (Norling and Rippenbein 17). 
Such degradation (as well as the addition of dirt into the scratch grooves, and thus the addition of further scratches on the same print) led projectionists to develop a metaphoric term for scratches: it was the "rain" (or "rainy") effect. ${ }^{2}$ In February of 1916, Moving Picture World published comical artwork that invoked this terminology. In it, a little boy and his mother watch scratchy footage in a movie theatre, but she believes the scratches are part of the narrative. The little boy has to explain to her, “Aw, ma. That ain't rain! That's scratches on the film!” (Fisher 766).

Collectively, these flaws were and remain the bane of film projectionists in the United States and throughout the globe. In 1937, one industry trade publication referred to them as "everyday screen defects," an indication of their common appearance (Schroeder 7). Certainly filmmakers were familiar with such problems, and also knew that audiences were aware of them as well. For example, the Academy-Award winning animated short subject Duck Amuck (Chuck Jones, 1953) parodies projection-booth troubles. Such references have become a growing trend in recent decades, one in which filmmakers have looked to the problems inherent in projection as a source of inspiration for filmic texts and paratexts.

For example, film damage does not appear in the silent film recreations in Chaplin (Richard Attenborough, 1992), or, for that matter, in the actual footage of Charles Chaplin contained therein, even when (as in the dramatization of Chaplin's appearance at the 1972 Academy Awards) the silent footage is supposed to be old within the context of the narrative. But for the DVD release in the United States in 1998, the menu screen featured black-and-white footage intentionally riddled with numerous scratches.

Indeed, during a period during which film historians, preservationists, and restorationists have sought to eliminate scratches and other blemishes from old film 
prints, filmmakers have often sought to add them intentionally for various aesthetic reasons. While at first this historically parallel but aesthetically inconsistent situation seems paradoxical, it can be explained by examining the rationale used by those working with film damage, not only by understanding that restorationists have different views on the subject, but also by examining the reasons why some directors have embraced film damage. Footage riddled with intentional scratches need not be riddled with questions, as an investigation of them yields a typology in which some scratches are added for diegetic purposes, some for non-diegetic purposes, and some for a third category that blurs the lines between that binary.

\section{The Film Projectionist in the United States:}

In 1924, Buster Keaton directed and starred in Sherlock Jr., his character being a motion picture projectionist. Falling asleep in his booth, he dreams that he has the ability to walk down the theatre auditorium and jump into the projected image, literally becoming a part of the onscreen action. The life of an American projectionist (or "operator," to use the common terminology of the early cinema and classical Hollywood eras) was less magical than Keaton's, but it was quite important, requiring much skill, particularly before the advent and proliferation of flat platter projection. As Thomas Alva Edison wrote in 1927, "In [the projectionists'] hands is the power to make or mar the pictures they receive" (17).

Such an opinion had deep roots. In 1910, the Film Index described the significance of film projection:

... when you go to see motion pictures, whether in a first-class theatre or the nickel house, there is one man upon whom the whole picture show practically 
depends, one man who can either make or mar the entire entertainment for which you have paid your admission, and that man is - not the proprietor, whose capital is invested in the show, not the manager who gives out orders so promiscuously, but a man you don't see at all, perhaps we up in a little 6x7 coop near the roof, the chap they call 'the operator' ("The Operator" 10).

Put another way, the projectionist was a person whose input greatly affected a film, even if his or her contributions occurred days, weeks, or even months after the film's production had wrapped.

During the nickelodeon era (circa 1905 to 1912), many U. S. cities and states required projectionists to be licensed. Projectionists also formed unions or became members in the International Alliance of Theatrical Stage Employees (IATSE) (Rhodes 109-113). As part of their responsibilities, projectionists had to prepare film prints, screen them repeatedly during their scheduled runs, and then prepare the same prints for return to film exchanges. Such work remained much the same over the ensuing decades, save for additional training required in order to project sound films successfully.

While the design of projection booths and the usage of specific technologies have evolved with some regularity, the projectionist's ability to "make or mar" a screening remains in place to the present day. For example, in August 2008, I attended a screening of Star Wars: The Clone Wars (David Filoni, 2008) at the Carmike Five Theater in Ardmore, Oklahoma. At a given point, the $35 \mathrm{~mm}$ print jammed and the heat of the projector bulb literally burned through a frame, the effects of which were projected onto the screen. The image largely disappeared, with strands of scorched film swaying to and fro. The projectionist - who was responsible for five 
booths simultaneously and was not physically present when the print jammed - had marred the screening, at least in the eyes of most of its viewers.

Another key issue facing projectionists has always been the presentation of a consistently stable, clear, and clean image. Here was the topic that those in the profession discussed frequently, at union conventions and within the pages of such industry trade publications as Moving Picture World, Motion Picture News, Exhibitors Herald, Motion Picture Herald, Motion Picture Projectionist, and International Projectionist. The following quotation from E. H. Pyle published in Moving Picture World in 1924 provides some indication as to the varying degree of skills possessed by operators:

I am myself [a] projectionist in a town of about 1,500 , and am proud of it. ... I take every possible care of the films which are entrusted to me, because I deem it my duty to do so. I always return them in as good, and not infrequently in better condition than when received.

I have received films in such wretched condition that it was utterly impossible to give a decent show without cutting out a goodly part of the picture. On the other hand, some of the films are in excellent shape....

... As to punch marks, scratch marks, and many other 'change-over' signals I have encountered, my opinion of the one who thus outraged the films is that he is a lazy, thoughtless cheapskate, who ought not to be allowed in a projection room at all (“Unfair?” 228). 
In the latter example, Pyle referred to intentional scratches made by projectionists as improvised change-over marks that helped to alert them when they needed to start the next reel on another projector.

None of this is to say that film prints projected on a large or even excessive number of occasions always become damaged. In 1947, a U.S. projectionist boasted that he had a "date trailer that has run 1,460 times and still hasn't a scratch on it" (Snow 32). Nevertheless, problems have plagued many film screenings, with the damage of yesterday remaining on prints that survive today, often to the chagrin of those who study and preserve films, as well as those who attempt to restore them by (amongst other tasks) the removal or minimization of scratches.

\section{$\underline{\text { Removing Scratches }}$}

Writing about surviving prints of Charlie Chaplin's Keystone films in 2011, Charles Maland noted:

... those still available were often stored in faraway archives and available only in scratched, poorly framed, fragmentary, or otherwise visually inferior condition. Despite visiting archives in Los Angeles, Washington, D.C., New York, London, and Stockholm to see all the Chaplin Keystones available in these locations, I still lacked a complete picture of how Chaplin learned to make films and how he developed his Tramp character during his first year in the industry (121). 
For Maland, scratches and other damage on these Chaplin short subjects exceeded the category of being minor flaws; they limited his ability to study the original visual content.

Those restoring films usually aim to eliminate such problems and return them to a close approximation of their original appearance. Given that scratches are the most common form of film damage, they are also one of the common flaws that restorationists have sought to remove or to limit using different methodologies. For example, silent film intertitles (or "subtitles," as they were originally called) that are heavily scratched can be corrected using more than one approach. As Kevin Brownlow has said, "I don't object to the freezing of titles [so as to limit the visibility of the scratches on them] ... It is certainly better to freeze an original title in its one readable frame, say, than to make up a phony-looking 'original' to try and match the rest" (Brownlow).

The number of film restorations has increased from the 1990s to the present, with many restorationists relying upon various forms of computer software rather than (or in addition to) more traditional methods. As Ariana Turci noted in 2006, "The archive chooses laboratories that have scanners equipped with wet gate elements because, in their opinion, it is the best method to delete scratches." Then, other phases of digital restoration sometimes take place "inside the archive," with restorationists using Retouche (developed at the University of La Rochelle) and Diamant software in order to "automatically delete dust and scratches and treat flickering and loss of information" (113). In some cases, as in a Filmoteca Espanola restoration of Un chien andalou (Luis Bunuel, 1929), digital software was used to eliminate scratches that "could not be alleviated with traditional photochemical wet gate reproduction" (115). 
Retouche and Diamant are hardly the only examples of such software. Blackmagic Design touts its "DaVinci Revival” as:

The world's best film restoration software with incredible features to repair all types of film damage ... Remove such problems as film grain, dust, dirt and scratches, eliminate scratches, kill flicker, fix registration and weave problems, and repair warping from bad splices (Blackmagic Design).

Similarly, Digital Vision advertises its "Phoenix Refine" as the "best high-end restoration toolset for repairing damage to film material" (Digital Vision). And Algosoft Tech's "Viva-Pro Software" promises that it can "repair the very toughest picture problems and remove amazing amounts of dirt and scratches" (Algosoft).

This kind of software usually allows for automatic and/or semi-automatic intervention, rather than the painstaking examination and correction of every single film frame. For example, in 2000, Bretschneider, Kao, and Bones proposed a technique of vertical scratch removal in digitized films based upon the discrete wavelet decomposition in the footage. An algorithm "reconstructs the missing data in the region of the scratch and finally the synthesis of the wavelet coefficients generates a restored version of the scratched image frame" (Bretschneider et al). Two years later, Haindl and Filip proposed their own algorithm for the "fast restoration of color movie scratches" (Haindl and Filip).

An increase in the number of film restorations has also led to increased discussion over whether or not scratches should be removed. In an interview with Andreas Busche, Joao Socrates de Oliveira argued: 
A scratch that has occurred during an earlier printing process becomes part of the film. Hence, I would advise to leave it. There is a dominant idea in our times that everything should look spotless. I do not think that is the most important thing. ... Even a faded print can have a beauty. There is an élan, a magic, that makes them a very interesting experience (Busche 23).

Paolo Cherchi Usai has likewise remarked, "It is acceptable to pay a lot of money for a sixteenth-century table which is full of scratches, and [we] have no intention whatsoever to [sic] its surface to make it look new" (24).

\section{$\underline{\text { Adding Scratches }}$}

While those who restore films might debate whether or not scratches and other damage should be removed, they do not advocate adding new damage to existing film prints. The very idea would generally provoke the ire of those who seek to preserve and study the history of cinema. And yet, as antithetical as it might at first seem including to some directors who hope to see their work preserved for future generations - many filmmakers intentionally scratch their own footage.

A number of avant-garde filmmakers have been particularly associated with this practice, including Len Lye, and, more famously, Stan Brakhage. Though not oppositional to Hollywood cinema, Brakhage's films were certainly an alternative to it. As David James has noted, "the attempt to defetishize technology and to subvert the repressive technical standards of the commercial film were phrased as an attempt to exploit the total resources of the medium" (38). Those resources included looking to the physicality of the medium as an aesthetic tool. Brakhage himself noted, "It takes me hours to scratch on film: By Brakhage" (40). 
But the practice predates Brakhage, with its first notable usage in the United States coming not in avant-garde cinema, but rather in Hollywood filmmaking. The News on the March sequence that begins Citizen Kane (Orson Welles, 1941) includes a small amount of footage that was intentionally scratched. This practice has become increasingly prevalent among Hollywood filmmakers since the 1990s, as has software used to add the digital appearance of film damage, including the insertion of scratches. Here is an irony, in that such software has been developed parallel to aforementioned software used to remove scratches.

The software used to create scratches arose as part of the larger project of attempting to grade video and digital images such that they would appear more filmlike (meaning the appearance of $35 \mathrm{~mm}$ film grain, frame rate, and density curve in terms of grayscale and contrast). With this software came the possibility of digitally adding stress and damage to footage, whatever its original source or condition. Filmlook, Inc., established in 1992, was one of the first companies to offer such possibilities. Subsequently, software like "Cinelook," the "Magic Bullet Suite," and "Film Effects" (a filter embedded in the Vegas software package) presented similar options to users.

"Film Damage" - a plug-in for Apple's Final Cut Pro included in the Nattressdesigned software "Film Effects" - represents a key example. Overall, Nattress' major goal with Film Effects was to allow users to import interlaced video footage and to de-interlace it, making it appear more like 24fps film. The "Film Damage" filter allowed users to choose scratch type (meaning black-and-white or color), the number, length, depth, weave, and thickness of the scratches; the appearance, frequency, length, life, curliness, thickness and blend of "hairs"; and the blend, amount and size of "dirt." As developer Graeme Nattress has described: 
For dirt, hair and scratches, the situation is complex as they're temporal effects, rather than on a per-frame basis. The scratches have a probability of occurring and then a length of time for which they'll last. Hair has to attach itself to the gate somewhere in the frame, with a tail that will wobble as the frames advance and finally shake itself loose (Nattress).

While sales of "Film Effects" have declined since the proliferation of HD cameras (that do not capture interlaced video), the software remains viable given that so many filmmakers continue to use the "Film Damage" filter.

In addition to relying upon digital effects, filmmakers can also composite their footage with pre-existing damaged film footage, which is readily available online from such companies as Artbeats Software, Inc. of Myrtle Creek, Oregon. Since 1996, Artbeats has offered a wide range of scratched film, old countdowns and head leader featuring handwriting, sprocket hole images (suggestive of footage temporarily unloosed from the projector gate), and burning film frames (Hill). As of 2016, the company released new footage on a monthly basis, a schedule that suggests how often filmmakers rely upon them.

The rise of interest in adding scratches to footage (or the digital appearance of the same) has also led to the rise of experts offering specific tutorials and training on the subject. For example, the Anvel company of Atlanta, Georgia, headed by Dean Velez, gives online and in-person workshops and classes on how to employ various software packages to translate HD video into what appears to be damaged film footage. Collectively, stock footage, digital software, and training on their usage has 
resulted not only from the desire of filmmakers to add scratches to their footage, but to add scratches for a variety of specific reasons.

\section{A Typology of Intentional Scratches}

Why did Orson Welles have editor Robert Wise intentionally scratch some of the faux-News of the March newsreel footage for Citizen Kane? To cause the appearance of projection stress and damage of course. But what was the purpose of imbuing what was at the time modern footage with visual flaws? The answer is simple, and might at first seem to encompass all intentional uses of film scratches: age. The particular images scratched for Citizen Kane were meant to appear like nonfiction footage from an earlier era, just as the scratches in Zelig (Woody Allen, 1983) would over four decades later. The scratches added a layer of verisimilitude, making the footage appear old.

It is difficult to determine exactly which Hollywood film first used scratches intentionally. In a 1933 review, Variety observed the following of Universal Pictures' short subject Boo (Albert DeMond, 1933): “Condition of print seemingly poor, though it may have been U's idea to make it that way to keep it plenty eerie" ("Talking Shorts" 12). In this instance, Variety understood the potential for film damage to be used as an aesthetic device and did not express surprise at the possibility. But whenever the effect was first employed, Citizen Kane remains the most famous early example, with its usage being diegetic, the scratchy footage viewed by the film's characters in a screening room.

Earlier filmmakers had certainly employed other means to make diegetic footage appear vintage. Irving Cummings’ 1939 Technicolor film Hollywood Cavalcade relied on black-and-white to help make its silent film recreations seem old 
(in tandem with the casting of actors who known for their work in silent cinema). Even though black-and-white film stock was the norm for Hollywood releases in 1939, Cummings used it as an aesthetic tool to make particular footage seem outdated in comparison to his otherwise color film narrative. But his footage features no damage, no wear-and-tear.

Incorporating pristine black-and-white footage inside a color film in order to depict earlier cinema practice can be seen in many other films, among them The Purple Rose of Cairo (Woody Allen, 1985), Bram Stoker's Dracula (Francis Ford Coppola, 1992), Matinee (Joe Dante, 1993), Inglourious Basterds (Quentin Tarrantino, 2009), and The Artist (Michael Hazanavicius, 2011). Film recreations in Ed Wood (Tim Burton, 1994) feature only minimal specks. Likewise, simulated home movie footage created for such films as The Graduate (Mike Nichols, 1967), Happy Gilmore (Dennis Dugan, 1996), and The Amityville Horror (Andrew Douglas, 2005) are not scratched. The same is true of the home movie footage in Rebecca (Alfred Hitchcock, 1940), which is pristine until damaged by Maxim (Laurence Olivier), who "threaded it up wrong."

Moreover, Hollywood filmmakers incorporating authentically old footage have not necessarily attempted to add damage or to use already-damaged prints. For example, diegetic clips that appear in movie theatre scenes in The Blob (Irvin S. Yeaworth, Jr., 1958), Bonnie and Clyde (Arthur Penn, 1967), The Last Picture Show (Peter Bogdanovich, 1971), Cape Fear (Martin Scorsese, 1991), Get Shorty (Barry Sonnenfeld, 1995), and Twister (Jan de Bont, 1996) feature either no wear or extremely minimal wear. The same is also true of the prison screening of Gilda (Charles Vidor, 1946) inside the narrative of The Shawshank Redemption (Frank Darabont, 1994). 
All that said, some directors did follow Welles' lead in the use of diegetic film damage, the first of three categories in which intentional film damage operates. Consider Kevin Brownlow's comments on It Happened Here (1965), the film he made with Andrew Mollo:

...we got a call from the BBC wanting to put a sequence on TV. We were far from finished - we were still shooting on $16 \mathrm{~mm}$ - but we recognised how useful such publicity would be. So we put together a Nazi propaganda newsreel, a la the March of Time parody in Citizen Kane. This went down so well we put it in the final film. And in order that it should look authentic, I sent the cutting copy, full of joins and scratches, to be blown up to $35 \mathrm{~mm}$. Fade out fade in.

Just a few years ago, I heard of an Italian documentary on Nazi propaganda, made by Rai-Tre, called La Grande Storia. Someone told me Rai-Tre had found a unique film made by the Nazis to prove to the occupied territories that the Germans had indeed invaded England. He sent me a tape and I eagerly ran down to the sequence he referred to. It was entirely shot by Andrew and me and while RAI had helped themselves to various parts of the film, they concentrated mostly on the newsreel-within-the-film. Incredibly, no one had spotted it, not even when the program was shown to a conference of historians and researchers at Venice (Brownlow).

Here is a clear example of the potential power of the diegetic film scratch. Brownlow and Mollo's scratchy Mirror on the World (as the faux newsreel in It Happened Here 
was titled) proved convincing not only to the film's characters, but also to real viewers, both novice and expert.

Though seldom seen during the classical Hollywood era, the use of the diegetic film scratch to emphasize the age of film clips has become increasingly common. The fake home movies in National Lampoon's Christmas Vacation (Jeremiah Chechik, 1989), the faux-newsreel footage in Up (Peter Docter and Bob Peterson, 2009) and the Smithsonian documentary in Captain America: The Winter Soldier (Anthony and Joe Russo, 2014): all of these use scratches for the simple effect of making modern footage look old, with the implication being that the scratches have occurred during repeated projection over a period of years or even decades.

A related usage of the diegetic film scratch appears in footage that is not necessarily meant to be old (though it might be), but instead meant to be unique and rare. Here one could think of the film-within-the-film in Them! (Gordon Douglas, 1954); the character Dr. Harold Medford (Edmund Gwenn) describes the scratchy footage he screens as "rare shots." The character Howard Hughes (Terry O’Quinn) implies the same of scratched, but modern (in the context of the narrative) Nazi jetpack test footage in Rocketeer (Joe Johnston, 1991); he goes so far as to claim someone died getting it out of Germany. Similarly, the narratives of The Hills Run Red (Dave Parker, 2009) and Chillerama (Adam Green et al., 2011) feature rare footage of faux-horror movies - "ultra-rare, Holy Grail shit," as a character in Chillerama explains - that is badly scratched.

The diegetic film scratch has also served to represent pornographic cinema. The poor quality of the footage speaks to the perceived poor quality of the film content. Dirty movies (in the narrative and thematic sense) are dirty (in terms of their 
film damage). Here again, it must be said that Hollywood filmmakers have not always opted for this approach. The simulated pornographic film footage within the running time of Kentucky Fried Movie (John Landis, 1977) is not intentionally damaged, nor is the simulated pornographic footage in The Big Lebowski (Coen Brothers, 1998) and in Lovelace (Rob Epstein and Jeffrey Friedman, 2013).

By contrast, a pronounced use of intentional film scratches does appear in several Hollywood films that include diegetic pornographic cinema. An early example is Paul Schrader's Hardcore (1979). Another is Paul Thomas Anderson's film Boogie Nights (1997). It features a film-within-a-film, a pornographic documentary profile of Dirk Diggler (Mark Wahlberg) directed by Amber Waves (Julianne Moore). All of the documentary footage - whether it is repurposed film from Diggler's pornographic movies or taken from new interviews that Amber conducted with Diggler and Reed Rothchild (John C. Reilly) - features a variety of scratches and specks. Television comedy has also relied on the same aesthetic, as can be seen in a 2011 episode of the Fox animated program Family Guy (Fox, 1999-). Entitled And I'm Joyce Kinney, the show includes clips of a faux-pornographic film entitled Quest for Fur that are replete with scratches.

The second key type of intentional film scratch is non-diegetic, which provides filmmakers with additional narrative and thematic opportunities beyond the simplicity of the scratch evoking pornography, rarity, or age. Indeed, the question logically arises as to whether film scratches are inherently suggestive of old film footage. After all, audiences would have had a complicated relationship with film scratches during the period in which Citizen Kane was produced. While studios generally eschewed the use of stock footage in their fictional film features during the silent era (as opposed to some independent filmmakers), they altered that strategy 
during the sound era. "Stock Footage in Common Use Among Producers After Years of Heated Opposition," a report in Variety headlined in 1932 (23).

If a particular image of a faraway country or exotic animal was needed, stock footage provided the answer. Thus, in many films that otherwise presented new and pristine images shot at major studios, stock footage might briefly appear, and in many cases it featured scratches and/or specks. The studios presumably hoped that audiences would either not notice the flaws or at least not be unduly distracted by them. The stock footage had narrative importance, but flaws on it did not have thematic purpose. For example, film damage on the concluding shots of Dr. Strangelove or: How I Learned to Stop Worrying and Love the Bomb (1964) - which depict nonfiction nuclear explosions - did not prevent Stanley Kubrick from using them. The importance of such images outweighed any objections that might have been raised about their visual quality.

The fact that some audience members do notice such scratches, at least to a degree, apparently led director Jay Roach to use scratchy stock footage (or create a simulation thereof) for the explosion at the climax of Austin Powers: International Man of Mystery (1997), in this case to parody the use of stock footage by earlier Hollywood filmmakers. While the narrative content of the footage is important to the film's plot, its visual quality is non-diegetic. The comedic effect is heightened not only because explosion appears so different to the quality of the footage of Austin Powers (Mike Myers) and Vanessa Kensington (Elizabeth Hurley) juxtaposed with it, but also because other, lesser explosions seen in the film are not represented by stock footage.

A more common usage of non-diegetic film scratches has been to invoke particular genres and exhibition practices in which films were screened over and over 
and over again. More specifically, this purpose has been to pay homage to exploitation films of the 1960s and 1970s. Such film prints were often screened at "grindhouse" theatres, becoming damaged from overuse and, at least in some cases, poorly maintained equipment. As a result, intentional visual stress in these films attempts to recall particular genres screened at particular kinds of venues. To an extent, the scratches and flaws imply age, but more importantly is also the implication of detritus: low-budget cinematic trash.

Examining such films under the rubric of what he terms "retrosploitation," David Church writes:

Importantly, the deliberate archaism used by retrosploitation practitioners, including, but not limited to, simulated material degradation, represents an imagined mix of historical use (as signs of affection through repeated screenings or handling) and historical neglect (as artefacts treated as undeserving of cultural longevity and thereby relegated to remembrance by niche taste groups) - without automatically marking the evaluative reasons for that use or neglect (126).

Church continues, noting that simulated "filmic dilapidation can very differently signify a retro-styled text's apparent value, depending on both the film-maker's and viewer's perceived degree of nostalgic reverence towards the text's historical referents" (126).

The most famous examples are Quentin Tarantino's Death Proof (2007) and Robert Rodriguez's Planet Terror (2007), released theatrically in the United States under the umbrella title Grindhouse so as to connect them directly to that exhibition 
tradition, to the extent that the joint release also included fake (and also intentionally damaged) coming attraction trailers for other grindhouse films. Death Proof and Planet Terror employed a combination of software plug-ins, stock footage, and physical damage to $35 \mathrm{~mm}$ footage to create their scratches, specks, and dirt. Subsequently, similar effects appeared in the opening sequence of Machete (Robert Rodriquez, 2010), and in the faux-trailer Machete Kills Again... In Space that opens the film Machete Kills (Robert Rodriguez, 2013).

Unlike the other films examined thus far, all of which embedded damaged footage into a narrative generally driven by pristine $35 \mathrm{~mm}$ footage, Death Proof and Planet Terror (the latter being shot on HD) utilize various kinds and degrees of film stress throughout the entirety of their running times. Death Proof and (even more so) Planet Terror feature not only scratches, but also weaving footage that appears momentarily freed from the sprocket holes and temporary lapses of focus. Likewise, other visual effects attempt to evoke a sense that the viewer is watching trashy cinema that has received little or no care from its owners or exhibitors, as in the fake burning film frames that Rodriguez edits into the opening and closing credits of Planet Terror. Caetlin Benson-Allott observes that the spectator of films like Death Proof and Planet Terror "meets" a "virtual" projectionist who is "virtually inept" (137). This projectionist never appears onscreen, but is a character in the film nonetheless, "implied through the plethora of projection errors, poor splices, and lost reels that shape the viewing experience." Of course the print damage remains the same even if the films are watched on home video or online, as opposed to in a movie theatre, which means it "reaches the spectator as a marker of simulacral cinematicity rather than a imitation of cinematic exhibition" (137). The unseen projectionist, in other words, remains a character, even when there is not a film projector. Nowhere is this 
clearer than in the James Bickert's “Dear God No!” (2011). In addition to the "original version," a 2013 home video release in the United Kingdom included a second DVD, the "Grindhouse Cut," which added a large number of digitally-created scratch and other damage effects to the original film. Comparison of the two prints underscores the absence and presence of the unseen projectionist.

The growing number of films that have incorporated diegetic and non-diegetic film damage has led to a third key type, arguably the most sophisticated of the three. In this final category, the lines between diegesis and non-diegesis become blurred. While the damage itself is usually seen only by the film audience, its usage becomes an expressionistic commentary on given characters, exteriorizing their inner thoughts, or, in other cases, amplifying upon unfolding narrative action that is ominous or evil. Film stress thus heightens the emotional stress of given characters.

For example, Oliver Stone's conspiracy-minded JFK (1991) features specks on cutaway footage while David Ferrie (Joe Pesci) describes his trip to Galveston, scratches and specks on footage of a militia training camp near Lake Ponchartrain, and scratches and specks on footage of the exterior of the Texas School Book Depository; likewise, similar damage appears on some fictional assassination footage created for the film. Film damage during $J F K^{\star}$ s running time is the most pronounced on footage of the Cuban Embassy in Mexico, seen when characters discuss whether or not the real Lee Harvey Oswald visited that location. To be sure, some of this damaged footage is meant to appear old, but some of it - such as Ferrie's trip to Galveston - is meant to depict narrative events that occur shortly before scenes that unfold in pristine footage. To a lesser extent, Stone uses similar damage in Nixon (1995), as in a pronounced scratch that appears during grainy, black-and-white 
fictional footage of the narratively recent Watergate break-in (as opposed to, for example, pristine black-and-white footage of Nixon's youth).

Stone's Natural Born Killers (1994) - which did not attempt to depict nonfiction historical figures or events - uses scratches and specks on the film solely to underscore the evil of the its leading characters, Mickey (Woody Harrelson) and Mallory (Juliette Lewis), as well as of the media, the police, and the prison system. Film scratches are most prevalent when Mickey escapes from prison guards on horseback, but they can also be seen briefly elsewhere, as in the scene that follows Mickey and Mallory's automobile running out of gas. Specks also appear on footage of Mickey and Mallory getting married, on the television recreation of them murdering a policeman, on footage of detective Scagnetti (Tom Sizemore) inspecting a car, and on a few shots of prison warden McClusky (Tommy Lee Jones).

A more pronounced use of film damage to express evil and violence occurs in the opening credits of David Fincher's Se7en (1995); scratches appear in conjunction with jumping frames and temporary loss of focus, as if due to warped/weaving footage in a projector. The visual content during those credits depicts the film's serial killer (Kevin Spacey) using a razor blade, thus creating a strong link between his narrative actions and the intentional film scratches. The brutal snuff footage in Joel Schumacher's 8mm (1999) features similar damage. ${ }^{3}$ Likewise, the Hughes Brothers' From Hell (2001) includes two opium-induced visions in which Inspector Frederick Abberline (Johnny Depp) sees murders committed by Jack the Ripper (Ian Holm). They are depicted in footage that features jumping frames, temporary loss of focus, as well as minor scratches and specks, but whether Abberline views the film damage that the audience views is not made clear. 
A related manifestation of this type of film damage appears during specific scenes in films like Planet Terror, Machete, and Eli Roth's fake trailer Thanksgiving (2007). On occasion, scratches or other prominent film damage appear onscreen at the moment of singular onscreen violence, operating akin to stingers on a soundtrack. These Visual Stingers, for lack of a better term, attempt to make such narrative action seem more gritty, more extreme, and more dangerous. In Planet Terror, for example, frame flutter occurs when El Wray (Freddy Rodriguez) smacks his fist into his other palm while driving. Scratches appear immediately after Dr. William Block (Josh Brolin) stabs his wife's hand with a hypodermic needle, as well as when Block is later killed. Moreover, the film seems bombarded by scratches when Cherry (Rose McGowan) first uses her machine-gun leg. In Machete, a pronounced, curved scratch appears exactly when the title character uses a gun from a severed hand to kill a member of a drug gang. The frame flutters when he kills the fourth gang member and again when he kicks open a door, thus knocking down yet another gang member. Then, at the moment his wife is decapitated, there is frame weave, as if the quality of the film frame expresses his frame of mind.

Perhaps the most pronounced occasion in which such a Visual Stinger has been used is in the Thanksgiving trailer, which was screened as part of the Grindhouse theatrical release. A killer with a butcher knife is on the loose. A teenage girl strips and jumps on a trampoline. She is nude save for a cheerleader's skirt. She does the splits in the air right after the killer punctures his butcher knife through the trampoline. Just before her genitalia lands on the blade, while she is still in midair, there are horizontal scratches, frame flutter, and other flaws, all of which underscores the evil and traumatic event about to occur. 
Film damage as Visual Stingers work successfully within films like Planet Terror in part due to the proliferation of scratches throughout the entire films. Put another way, if a film that featured little or no film damage incorporated a scratch as a Visual Stinger, it would likely be understood as an unintentional flaw on the print rather than as an intentional aesthetic device. The limited number of Visual Stingers in the films under discussion arguably intensifies their impact, their appearances being unexpected and thus more dramatic.

\section{Conclusion:}

Given the widespread usage of film damage as an aesthetic device, two factors are worth noting, the first being not unexpected. Accidental film scratches created during projection can sometimes cause static on a film's soundtrack. The same filmmakers who intentionally incorporate scratches into modern footage have not usually imitated such aural static. It has been a longstanding feature of Classical and Post-Classical Hollywood to privilege audio, that soundtracks are as clearly recorded as possible. Advances in surround sound for both the theatre and home entertainment since the 1980s have further discouraged filmmakers from intentionally degrading the audio of their own footage.

However, the second factor is somewhat surprising. Directors intentionally damaging their footage have not usually appropriated the aesthetics of projectionbooth editing styles. Whether it involved last-minute censorship and thus rapidly excising footage, carefully (or not) splicing together film reels (or footage torn within a given reel), correctly (or incorrectly) ordering all reels that constituted a film, or timing the start of a film such that leader tape or countdown footage would not appear onscreen, projectionists have played a minor role in the editing process. This role has 
notably been addressed within film narratives (whether it is excising footage, as in the plot of Cinema Paradiso [Guiseppe Tornatore, 1998], or discussing the purpose of changeover marks, as in the plot of Fight Club [David Fincher, 1999]).

To the extent that projection-booth editing has informed film aesthetics, it has occurred since the 1990s. For example, one can cite the faux-trailer for Mant seen during the feature Matinee (in which an aural pop mimics the loss of magnetic soundtrack due to a rough projection booth edit), the opening credits of Se7en (in which head leader footage is seen), the replacement opening title and the "missing reel" in Death Proof (as well as an aural pop on leader footage and on an intentionally rough edit), and the missing reel in Planet Terror (as well as countdown footage seen during its closing credits). These are all in addition to The Last Temptation of Christ (Martin Scorsese, 1988), which concludes its narrative by cutting to red leader footage (on which a minor scratch can be seen).

Perhaps the minimal appropriation of projection booth editing as compared to the use of damage like scratches is understandable. In 1960, the International Projectionist referred to the "ubiquitous scratch problem," as by that time scratches had already plagued operators for over six decades" (Mitchell 8). As of 2016, scratches, specks, and dirt have been film problem for 120 years, and a film aesthetic for over 70 years. At least in the near term, filmmakers will continue to employ intentional scratches and other damage for purposes ranging from the diegetic to the non-diegetic and the nebulous area between the two. Scratched film need not be considered worthless; rather, it can be evocative of particular eras, genres, and exhibition venues.

By contrast, archivists looking to preserve $35 \mathrm{~mm}$ positive prints of films like Planet Terror and Death Proof face a daunting task. With all of the intentional visual 
stress that such directors have embedded in these kinds of movies, the fact that release prints might have incurred additional and unintentional damage will serve to amplify and indeed complicate the philosophical questions that are already present. Will a restorationist someday attempt to remove unintended scratches from a print of Machete, while carefully preserving those that Robert Rodriguez intended? Only time will tell.

Acknowledgments: The author would like to thank the following persons for their assistance in the research for this essay: Kevin Brownlow, Robert Gitte, Michael E. Lee, Hugh Manon, Robert Singer, and Anthony Slide.

\author{
Works Cited
}

Advertisement. New York Clipper, 15 Nov. 1902, p. 856.

Algosoft, 'Restoration Professionals' (2014), accessed October 20, 2014, http://algosoft-tech.com/.

Benson-Allott, Caetlin. Killer Tapes and Shattered Screens: Video Spectatorship from VHS to File Sharing. University of California Press, 2013.

Blackmagic Design. "DaVinci Revival.” 2014. www.blackmagicdesign.com/products/davincirevival/. Accessed 21 Nov. 2014.

Bretschneider, T., O. Kao, and P. J. Bones. "Removal of Vertical Scratches in Digitised Historical Film Sequences Using Wavelet Decomposition." Proceedings of the Image and Vision Computing New Zealand. 2000.

citeseerx.ist.psu.edu/viewdoc/summary?doi=10.1.1.100.3261. Accessed 15 Nov. 2014.

Brownlow, Kevin. Email to Gary D. Rhodes. 23 May 2016. 
Busche, Andreas. "Just Another Form of Methodology? Ethical and Methodological Principles in Film Restoration.” The Moving Image, vol. 6, no. 2, Fall 2006, pp. 1-29.

Church, David. Grindhouse Nostalgia: Memory, Home Video and Exploitation Film Fandom. Edinburgh UP, 2015.

Decker, Francis W. "The Care of Motion Picture Film.” The American Archivist, vol. 25, no. 3, July 1962 , pp. 357-359.

Digital Vision. "Phoenix Film Restoration Software." 2014.

www.digitalvision.tv/products/phoenix film restoration/. Accessed 28 Oct. 2014,

Edison, Thomas A. Letter. Motion Picture Projectionist, Oct.1927, p. 17.

Fisher, Thornton. Untitled Artwork. Moving Picture World, 5 Feb. 1916, p. 766.

Haindl, Michael and Jirí Filip. "Fast Restoration of Color Movie Scratches." 2002. staff.utia.cz/filip/papers/haindl02fast.pdf. Accessed 7 Nov. 2014.

Hill, Julie. Email to Gary D. Rhodes, 21 Oct. 2014.

James, David. "The Film-Maker as Romantic Poet: Brakhage and Olson." Film Quarterly, vol. 35, no. 3, Spring 1982, pp. 35-43.

Maland, Charles, "Chaplin at Keystone Restored." The Moving Image, vol. 11, no. 2, Fall 2011, pp. 120-124.

Mitchell, Robert A. "Projection Quality and Release Prints.” International

Projectionist, Dec. 1960, p. 8.

Nattress, Graeme. Email to Gary D. Rhodes. 21 Oct. 2014. 
Norling, J. A. and Albert P. Rippenbein. "The Rejuvenation and Preservation of Films." Motion Picture Projectionist, Nov. 1931, p. 17.

"Operator is the Man, The." The Film Index, 12 Nov. 1910, p. 10.

"Projector Head and Rewind Cause Most Film Scratch Marks.” International Projectionist (August 1932), p. 22.

Rhodes, Gary D. The Perils of Moviegoing in America, 1896-1950. Continuum, 2011.

Richardson, F. H. "Film Damage! What's the Real Cause?" Moving Picture World, 3 Jan. 1925, p. 97.

Schroeder, A. C. "Film Scratches: Some Causes and Means for Their Elimination." International Projectionist, May 1937, p. 7.

Slide, Anthony. Nitrate Won't Wait: A History of Film Preservation in the United States. McFarland, 1992.

Snow, E.A. Letter. International Projectionist, July 1947, p. 32.

"Stock Footage in Common Use Among Producers After Years of Heated Opposition.” Variety, 1 Mar. 1932, p. 23.

“Talking Shorts.” Variety, 14 Feb. 1933, 12.

Turci, Arianna. "The Use of Digital Restoration within European Film Archives: A Case Study." The Moving Image, vol. 6, no. 1, Spring 2006, pp. 111-124.

“Unfair?” Moving Picture World, 15 Mar. 1924, p. 228.

Usai, Paolo Cherchi. The Death of Cinema: History, Cultural Memory and the Digital Dark Age. British Film Institute, 2001. 
${ }^{1}$ For more information on this subject, see: Alvarez, Max Joseph. "The Origins of the Film Exchange." Film History: An International Journal, vol. 17, no. 4, 2005, pp. 431-465.

2 Discussion of scratches as "rain" appears in Braun, William T. "Problems of the Operating Room." Motography, Feb. 1912, p. 76, and in "Questions and Answers." International Projectionist, Oct. 1931, p. 22.

${ }^{3}$ Here I am specifically referring to the initial depiction of snuff footage in $8 \mathrm{~mm}$. 